
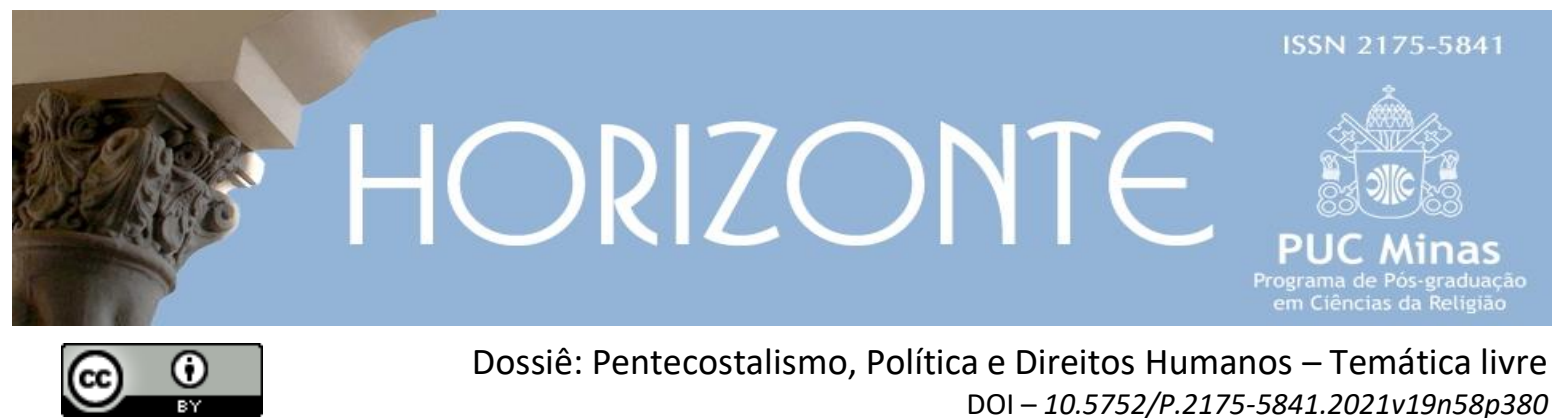

\title{
Édipo Rei, José e Cântico dos Cânticos: da tragédia grega à contratragédia bíblica
}

\author{
Oedipus the King, Joseph and the Song of Songs: from Greek tragedy to \\ biblical counter-tragedy
}

Osvaldo Luiz Ribeiro*

\begin{abstract}
Resumo
O artigo procura ler a história de José, em Gênesis, como uma narrativa do gênero tragédia, e, mais especificamente, uma tragédia que tem como modelo Édipo Rei. Ao mesmo tempo, o artigo procura ler Cântico dos Cânticos como uma narrativa que, atualizando-se na forma de uma narrativa também exatamente no modelo de Édipo Rei, subverte, todavia, o enredo trágico por meio da crítica político-social de que o que aparece como determinação divina no oráculo somente funciona no nível da realidade humana por força da cumplicidade entre representantes das classes dominadas, a que se dirigem os mitoplasmas, e a classe dominante, que os engendra. No campo narrativo, em Cântico dos Cânticos, a incompetência tática das personagens de Edipo Rei e de José, que, julgando escapar do destino oracular, findam por promovê-lo, corresponde à denúncia da cumplicidade do homem que, na composição, domina a heroína, o qual, em conluio com a classe dominante, responsável esta pelo oráculo de maldição que recai sobre as mulheres daquela cultura, ratifica o enredo trágico ao aceitar cumprir seu papel na encenação dos destinos em jogo.
\end{abstract}

Palavras-chave: Édipo Rei. Tragédia. José no Egito. Cântico dos Cânticos. Contratragédia.

\begin{abstract}
The article seeks to read the story of Joseph in Genesis as a narrative of the genre tragedy, and more specifically, a tragedy that has as model Oedipus King. At the same time, the article seeks to read Song of Songs as a narrative that, updating itself in the form of a narrative also exactly in the model of Oedipus King, subverts, nevertheless, the tragic plot through the social-political critique of that what appears as divine determination in the oracle only functions on the level of human reality by virtue of the complicity between representatives of the dominated classes, to which the oracles are directed, and the ruling class, which engenders them. In the narrative field, in Song of Songs, the tactical incompetence of the characters of Oedipus King and Joseph, who managed to escape the oracular destiny, end up promoting it, corresponds to the denunciation of the complicity of the man who dominates the heroine, in collusion with the ruling class, responsible for the oracle of curse that falls on the women of that culture, ratifies the tragic plot by accepting to fulfill its role in staging the destinies at stake.
\end{abstract}

Keywords: Oedipus King. Tragedy. Joseph in Egypt. Song of Songs. Counter-tragedy.

Artigo submetido em 10 de julho de 2018 e aprovado em 8 de julho de 2021.

* Doutor em Teologia (PUC-Rio). Professor do Mestrado em Ciências das Religiões da Faculdade Unida de Vitória. País de origem: Brasil. E-mail: osvaldo@faculdadeunida.com.br 


\section{Introdução}

Quem dera fosses como um irmão para mim. (Ct 8, 1).

Devendo ser tomado como uma primeira aproximação ao tema, à qual devem ser necessariamente somadas outras, o presente artigo tem por objetivo comparar as histórias José $(\mathrm{Gn} 37,48)$ e Cântico dos Cânticos com a tragédia Édipo Rei, de Sófocles. Assume-se que José constitua propriamente uma tragédia do tipo Édipo Rei, e que, ainda que se servindo dele, Cântico dos Cânticos ultrapasse o referido modelo, objetivando a crítica político-social da instrumentalização do enredo trágico para fins do controle social do mundo da mulher, que a composição denuncia.

Para os fins deste artigo, a tragédia do tipo Édipo Rei constitui-se pelo enredo fatalista, nos termos do qual as determinações divinas logram concretizarem-se, a despeito de quaisquer esforços que quaisquer personagens façam para escapar ou fazer escapar do destino em jogo. Sem qualquer exceção, nas três narrativas, oráculos anunciam o destino inexorável do herói. Em Édipo Rei e Cântico dos Cânticos, um destino negativo, e, em José, um destino positivo para o herói, mas interpretado como negativo pelos irmãos. Nas três composições, diferentes personagens envolvidos acionam estratégias e táticas para evitarem o destino anunciado pelos oráculos. Unanimemente, até certa altura das três narrativas, as ações das personagens parecem ser bem-sucedidas, até que, a partir de determinado momento, o desenrolar dos acontecimentos leva irremediavelmente os heróis a cumprirem exatamente o papel que lhes fora divinamente prescrito. Nos três casos, nada que pessoa alguma possa fazer modifica o destino traçado pelos deuses. Em Édipo Rei, lamenta-se o destino inexorável. Em José, perdoam-se os responsáveis pela inicial aparência de desgraça a que o herói fora submetido, e louva-se o deus a quem se remonta a direção inexorável de todos os eventos. Nos dois casos, os deuses são reconhecidos como os verdadeiros operadores dos destinos. Por sua vez, em Cântico dos Cânticos, negase que haja qualquer destino divinamente traçado, e interpreta-se a desgraça final 
da heroína como o resultado do conluio entre atores sociais, cuja hipóstase mitoplástica ${ }^{1}$ constituiria o enredo trágico.

\section{A tragédia Édipo Rei}

Se aceitarmos a específica interdição que Vernant e Vidal-Naquet (1990) impõe à investigação quanto ao sentido de Édipo Rei, então teremos de nos ater, como prescrevem, apenas à "própria obra" (VERNANT; VIDAL-NAQUET, 1990, p. 8-9, tradução nossa) ${ }^{2}$, e unicamente aos elementos inerentes à "sua estrutura, sua organização interna” (VERNANT; VIDAL-NAQUET, 1990, p. 8-9, tradução nossa). 3 Forçando-nos a recordar a lição de Umberto Eco (1993), os autores declaram que "nós não temos meios de retroagir da obra até seu autor" (VERNANT; VIDALNAQUET, 1990, p. 9, tradução nossa) 4, de sorte que, para especular a respeito da "intenção da obra", restaria aos investigadores permanecerem presos ao seu objeto imediato. Experimentemos, então, permanecer, na obra5.

Já próximo do final da narrativa, quando os eventos trágicos que envolvem a vida de Édipo começam a ser revelados, diretamente envolvidos na trama, o mensageiro e o pastor são interrogados pelo rei. O pastor que diz ter recebido de Jocasta a criança a ser abandonada para a morte, parece saber o que está em jogo. $\mathrm{Na}$ entrevista que Édipo faz com o velho pastor, este diz ao rei que Jocasta lhe entregara a criança $^{6}$, com o propósito explícito de que fosse exterminada (SÓFOCLES, 1998, 1. 1375-1376), e que a razão do ato, que a Édipo parece "incrível" (SÓFOCLES, 1998, 1. 1377), é que Jocasta "tinha receio de uns oráculos funestos" (SÓFOCLES, 1998, 1. 1378), isto é, "diziam que o menino mataria o pai" (SÓFOCLES, 1998, 1. 1380). Na sequência narrativa, quando Édipo pergunta por que o entrevistado entregou a criança ao outro ancião, a resposta é: "por piedade, meu senhor; pensei, então, que ele o conduziria a um lugar distante de onde era

\footnotetext{
${ }^{1}$ Com a expressão "hipóstase mitoplástica" quer-se, nesse contexto, indicar para a projeção do conflito social na forma de mito político-teológico, a partir do qual as classes dominantes intervêm na sociedade.

${ }^{2}$ The work itself

3 Its structure, its internal organization

${ }_{4}$ We have no way of reaching back from the work to its author.

5 Para um conjunto de interpretações de Édipo Rei, veja Dodds (1966); Bloom (2007).

${ }^{6}$ Cf. as linhas 1370-1374 de Édipo Rei (1998). As referências aos versos de Édipo Rei serão feitas a partir da tradução de Mario da Gama Kury, seguindo inclusive a numeração dos versos presente na referida obra. Cf. Sófocles (1998).
} 
originário; para nosso mal ele salvou-lhe a vida.” (SÓFOCLES, 1998, l. 1382-1385). $\mathrm{O}$ que isso quer dizer?

Bem, não vamos investigar se o pastor está pretendendo que seja crido que, ao entregar a criança ao colega pastor, sua intenção teria sido que este a matasse ainda mais longe, interpretação que se pode fazer com sua última declaração citada: "para nosso mal ele salvou-lhe a vida" (SÓFOCLES, 1998, 1. 1380), ou se com isso ele apenas assinala a consequência última da ação do agora mensageiro. $\mathrm{O}$ que interessa aqui é se o pastor que recebeu a criança das mãos da rainha tinha ciência dos oráculos, e, pelo que se viu, tinha: segundo seu depoimento, Jocasta "tinha receio de uns oráculos funestos" (SÓFOCLES, 1998, 1. 1378), que "diziam que o menino mataria o pai” (SÓFOCLES, 1998, 1. 1380). Nesse caso, quando o pastor decide entregar a criança ao seu colega de ofício, tem em mente a tentativa de, sem cumprir a ordem da rainha, ainda assim furtar a criança a seu destino horrível. Os "oráculos funestos" (SÓFOCLES, 1998, l. 1380) poderiam ser evitados, para o que não se precisaria matar a criança, mas afastá-la o mais possível "de onde era originário" (SÓFOCLES, 1998, 1. 1378). Ainda que não fosse a mesma estratégia da rainha, tinha a mesma intenção: evitar o destino trágico imposto pelo oráculo.

Pode-se alegar que se trata de uma estratégia mais humana que a da própria mãe da criança, mas isso não está em discussão, nem aqui nem na própria tragédia. Nunca integralmente explicitada pela rainha, a perspectiva do casal real quanto ao destino da criança fora exposta, parcialmente, antes. Quando Édipo e Jocasta conversavam sobre as angústias que assolavam o coração do herói, a rainha lhe faz saber que um intérprete de Febo anunciou a Laio que um filho dele com Jocasta o mataria (SÓFOCLES, 1998). Com a intenção clara de impedir o cumprimento do oráculo, segundo o testemunho de Jocasta, Laio teria tomado a criança, quando ela tinha três dias, amarrado seus tornozelos e a entregue a estranhos, que o teriam abandonado nas montanhas (SÓFOCLES, 1998). Sempre segundo o depoimento de Jocasta a Édipo, rei e rainha julgaram, então, que o oráculo havia sido frustrado: "naquele tempo, Apolo não realizou as predições: o filho único de Laio não se tornou o matador do próprio pai.” (SÓFOCLES, 1998, 1. 862-864). Como não se 
está julgando a correção do conhecimento de Jocasta quanto aos fatos, mas as intenções do casal real quanto a matar a criança, deve-se concluir que agiram premeditadamente para impedir o cumprimento do oráculo, objetivo que, alheia aos fatos tal como efetivamente se deram, Jocasta, equivocadamente, considera ter sido bem-sucedido.

Até aqui, a tragédia dá a saber à plateia que por duas vezes tentou-se escapar do destino determinado pelos deuses. Isso porque, para todos os fins, em Édipo Rei (1998), são os deuses que prescrevem os “destinos”. Não é o caso de corrigir o que Vernant e Vidal-Naquet dizem: “Expresso pela palavra daimon, o destino de Édipo é visto como um poder sobrenatural ligado à sua pessoa, que dirige o curso de toda a sua vida. " (VERNANT; VIDAL-NAQUET, 1990, p. 78, tradução nossa)7, mas de precisar que, nos termos da tragédia analisada, esse daimon é expressão do desígnio dos deuses. Com efeito, primeiro, Jocasta e Laio decidem exterminar a criança. Tivessem tido a coragem de eles mesmos concluírem o serviço, dificilmente Sófocles poderia ter desdobrado a narrativa, como, por exemplo, se poderia depreender da seguinte declaração: “quaisquer que fossem as intenções do autor, não haveria debate trágico se os outros protagonistas deixassem de se encolerizar." (GIRARD, 2008, p. 92)8. Uma vez que a tragédia é, para todos os fins, uma função narrativa determinada pelo autor, a intenção de Jocasta e de Laio em se furtarem ao destino precisa conter um elemento que faculte o malogro, e esse elemento é justamente a sua decisão, malfadada, de terceirizarem ao escravo a execução do serviço. Não pudesse ser malograda a tática do casal, Sófocles não poderia ter concebido uma tragédia desse tipo, porque Édipo Rei somente existe se Édipo efetivamente viver para matar o próprio pai e deitar-se com a própria mãe. Por isso, manipulados como deliberadamente incompetentes, os personagens

7 Expressed by the word daimon, Oedipus' destiny is seen as a supernatural power attached to his person, which directs the course of his whole life.

${ }^{8}$ Não se chega a extrair dessa questão as implicações necessárias. Conquanto tenha em mente o mesmo horizonte de raciocínio, o que se pode comprovar pela citação de argumento citado, isto é, a cólera dos personagens é um artifício a que o autor é obrigado a recorrer, o próprio Girard age como se a violência exposta na tragédia pudesse ser objeto/espelho para se falar da violência que se dá no nível da realidade. Ora, como o próprio Girard acabou de dizer, tudo se resume a obrigações a que o autor se vê imposto por força do gênero que desenvolve. Soa artificial a vinculação inexorável entre a violência no nível narrativo e a violência no nível da realidade, quanto mais se pretende que aquela seja espelho direto desta. 
precisam servir-se de táticas ineficientes, ineficazes, porque disso depende Édipo Rei, disso depende Sófocles (1998).

Função narrativa fundamental, sem a qual não há tragédia, a terceirização da execução do extermínio da criança cria a segunda possibilidade de marcar a narrativa com o motivo da tentativa de se furtar ao destino traçado pelos deuses. $\mathrm{O}$ escravo deveria exterminar a criança. Ora, como se viu, se Jocasta ou Laio tivessem, eles mesmos, matado o bebê, isso teria implicado na inviabilidade da tragédia. Da mesma forma, se o escravo tivesse cumprido a determinação que, segundo ele, não Laio, mas a própria Jocasta teria dado, não se teria tragédia. Morta a criança, efetivamente o destino traçado pelos deuses teria sido malogrado... Mas, nesse caso, não se trataria de destino divino. Isso posto, só resta a Sófocles criar o expediente de também impedir que o escravo mate a criança. Com efeito, o escravo é posto a declarar que, por piedade, entregou-a a outro pastor que, por sua vez, deixou-a viva. Curioso observar que, na tragédia, o destino determinado pelos deuses aos personagens trágicos depende inexoravelmente da ação desses mesmos personagens...

Retornemos ao enredo. Não são as duas já analisadas as únicas vezes em que a narrativa de Sófocles chama a atenção da plateia para a tentativa dos personagens de se livrarem do destino fatídico. O próprio Édipo julgou fazê-lo. Em seu angustiado diálogo com a rainha e então esposa, após a revelação desta de, a fim de evitar o destino, ter Laio executado o recém-nascido, Édipo conta que teria ele mesmo consultado o oráculo de Delfos, e que Apolo lhe teria revelado que ele se deitaria com a própria mãe, após ter assassinado o próprio pai (SÓFOCLES, 1998). Com o propósito deliberado de fugir ao destino traçado, julgando que seu pai e mãe eram aqueles que o haviam criado, desconhecendo que nascera de Laio e Jocasta e que fora poupado por conta de malfadadas estratégias dos verdadeiros pais e da deliberação piedosa do escravo, Édipo foge. Assim, “[...] essas predições [...] jamais se tornariam realidade." (SÓFOCLES, 1998, 1. 947 e 950). 9 Mal sabe ele que é justamente essa sua ação que recoloca nos trilhos o trem trágico. É sempre Sófocles

${ }_{9}$ Cf. linhas 1182-1187 em Sófocles (1998). 
a agir, sabemos, mas, com boa vontade, mantendo-nos na região da "obra": ironia, o próprio Édipo promove as condições para que o destino terrível que os deuses lhe reservaram finalmente se cumpra. Com efeito, porque foge de Corinto, exatamente como os deuses determinaram, Édipo mata o pai e se casa com a mãe.

Por três vezes, portanto, e por meio de três personagens diferentes, Édipo rei explicita o motivo da tentativa humana de fugir ao destino traçado pelos deuses. Ainda que Vernant (1978) interprete como "ambiguidade" o fato de que tanto Tirésias quanto Jocasta e o pastor tentarem impedir que Édipo descubra o que realmente se encontra no final de sua investigação, o que, para Vernant, deve ser interpretado como a prova de que Édipo é quem, sozinho, cava sua própria cova (VERNANT, 1978; GIRARD, 2008) ${ }^{10}$, em Édipo Rei, Édipo não é o único que tenta fugir ao destino traçado pelo oráculo. Jocasta chega a considerar que "falharam os oráculos” (SÓFOCLES, 1998, 1. 868). Édipo tem a intenção de fugir para que as predições jamais se tornem realidade (SÓFOCLES, 1998, 1. 950). Por piedade, ele disse, o escravo de Laio entregou a criança ao outro pastor para que fosse levada para "um lugar distante de onde era originário" (SÓFOCLES, 1998, 1. 1383-1384). Não se trata de um motivo secundário. Antes, pode-se dizer que é sobre ele que a narrativa se constrói, sem o qual, já se disse, ela inexiste inclusive como enredo.

Uma série de citações deve ser transcrita aqui. Elas estabelecem eixos de arrimo ao motivo que se acaba de mencionar. São elas: "eu não serei então um homem de verdade se não fizer tudo que o deus ditar. " (SÓFOCLES, 1998, 1. 9698); “querendo o deus [...] teremos satisfeito este nosso desejo." (SÓFOCLES, 1998, 1. 179-180); "ninguém detém poder bastante para constranger os deuses a mudar os seus altos desígnios. " (SÓFOCLES, 1998, 1. 333-335)¹; “os deuses tudo podem” (SÓFOCLES, 1998, 1. 453); “executar depressa e bem as ordens nítidas do deus. " (SÓFOCLES, 1998, 1. 490-491). Some-se a essas, ainda esta: "nuvem negra

\footnotetext{
${ }^{10}$ Cf. p. 99, nota 2 em Girard (2008).

11 A rigor, bastaria Laio ou Jocasta terem afogado a criança na bacia em que fora lavada, e os "altos desígnios" dos deuses teriam sido instantaneamente "constrangidos". Mas, como já se disse acima, Sófocles não pode fazer o que, em termos táticos, seria o mais óbvio. Logo, serve-se de um escravo. Se o escravo, todavia, efetivamente matar a criança, os "altos desígnios" dos deuses novamente se "constrangem". Por isso - e apenas por isso - Sófocles é obrigado a fazer com que também o escravo não faça o óbvio, e termine por entregar a criança a um terceiro que, por sua vez, a entregará a Pôlibo e Mérope. Para que a tragédia funcione, todavia, Sófocles precisa que não prestemos atenção a esses "detalhes”.
} 
de trevas, odiosa, que tombaste do céu sobre mim, indizível, irremediável, que não posso, não posso evitar.” (SÓFOCLES, 1998, 1. 1556-1559). No conjunto, tais citações prescrevem uma economia: os deuses determinam a vida dos seres humanos, e os seres humanos devem se submeter às injunções dos deuses.

Não se trata de apenas crer. Trata-se de submissão ao desígnio. No final da tragédia, Édipo já tendo vazado os próprios olhos, Creonte diz que consultará o oráculo a respeito do destino que agora deve caber ao desgraçado herói. “Consultarás então o oráculo a propósito de um miserável como eu? Será preciso?” (SÓFOCLES, 1998, 1. 1711-1712), diz Édipo, dirigindo-se a Creonte, que responde assim: "e desta vez crerás em suas predições" (SÓFOCLES, 1998, 1. 1713). Como assim “desta vez crerás"? Em todo o corpo da tragédia, alguma vez, algum personagem não creu nas predições? Laio e Jocasta não fizeram o que fizeram simplesmente porque creram nelas? O escravo não entregou a criança ao pastor, para que a levasse para longe de Tebas, justamente para que se evitasse o destino decretado pelos deuses? O próprio Édipo, conquanto fazendo seus cálculos com ábaco descalibrado, não fez o que fez porque creu que as desgraças efetivamente se sucederiam? Ora, todos creram... Não está em jogo crer, mas submeter-se. Submeter-se é o que nem Laio nem Jocasta nem o escravo nem Édipo fizeram. Quando, pois, Creonte diz a Édipo que vai consultar o oráculo, e que, desta vez, Édipo deve “crer” neles, não está falando em crer, mas em obedecer, submeter-se. Dessa vez, Édipo, vais se submeter ao que os deuses determinarem. Não vais tentar fugir do destino, mas encará-lo. Não se trata, portanto, de crença, mas de capitulação. Porque, afinal, se trata de que "necessitamos [...] de serenidade para executar depressa e bem as ordens do deus” (SÓFOCLES, 1998, 1. 490-491).

Essa leitura pode ser sustentada por meio de algumas escoras retóricas. Quando narra os acontecimentos relativos a como ela e seu marido se teriam livrado da criança que, assim queriam os oráculos, mataria um e dormiria com a outra, Jocasta diz que "falharam os oráculos" (SÓFOCLES, 1998, 1. 868). E falharam pelo fato de, em lugar de Jocasta e Laio terem se submetido aos oráculos, driblaram-nos - pelo menos assim pensavam. Com o assassino morto, Laio não 
poderia, por ele, ser abatido. Jocasta e Laio não se submetem ao oráculo. Por sua vez, quando Édipo foge de Corinto, ele julga que, assim o fazendo, as "predições [...] jamais se tornariam realidade” (SÓFOCLES, 1998, 1. 947-950). Édipo tinha a intenção de burlar as predições, de reescrever seu destino, e isso significa não se submeter ao roteiro traçado pelas predições. Não se trata de crer nelas. Trata-se de não se submeter a elas. E “assim pensava eu” (SÓFOCLES, 1998, 1. 951), diz Édipo, julgando que acabara de ter bem-sucedida sua insubordinação. Mais adiante, ainda crendo que os oráculos haviam sido frustrados, Jocasta brada: “oráculos dos deuses! A que ficastes reduzidos neste instante!” (SÓFOCLES, 1998, 1. 1124-1125). É o momento em que, informada de que Pôlibo, até agora tomado como pai de Édipo, havia morrido. Jocasta manda que sua criada vá avisar a Édipo que seu pai está morto, e que a morte não se deu por suas mãos (SÓFOCLES, 1998), de sorte que se poder ver “aonde levam os oráculos dos deuses” (SÓFOCLES, 1998, 1. 1131). Quando Édipo ouve a notícia, é a sua vez de desmerecer os oráculos: “por que, mulher, devemos dar tanta atenção ao fogo divinal da profecia pítica, ou, mais ainda, aos pios das etéreas aves?” (SÓFOCLES, 1998, 1. 1142-1144), acrescentando que, "segundo antigas predições eu deveria matar meu próprio pai” (SÓFOCLES, 1998, 1. 1145-1146), e, no entanto, conforme acredita Édipo, ele agora repousa, morto, mas não pelas mãos do filho (linhas 1146-1148). Aos olhos de Édipo, e, segundo a anotação redacional do diretor de cena, Sófocles, "ironicamente" (SÓFOCLES, 1998, 1. 1149), a morte de Pôlibo leva junto "as tristes profecias" (SÓFOCLES, 1998, 1. 1153-1154), razão que lhe parece mais do que suficiente para a conclusão que horrorizaria os instrumentos divinos que operam o sistema: "não, esses oráculos carecem todos de qualquer significado" (SÓFOCLES, 1998, 1. 11541155).

Resta ainda uma escora retórica. Na verdade, a mais robusta. Ela se constrói pela fala do coro, quando termina o angustiado diálogo entre Édipo e Jocasta, e ambos planejam certificar-se de que, como rezam os depoimentos antigos, Laio foi morto por um grupo, e não por um homem só, fato que, definitivamente, excluiria a possibilidade de que o homem que Édipo matara na "encruzilhada tríplice" (SÓFOCLES, 1998, 1. 957) era Laio. Por sua vez, Jocasta aprofunda o raciocínio: se 
forem confirmados os relatos antigos, não apenas Édipo não é o assassino, mas, mais importante do que isso, de nenhuma forma se provará "que o crime perpetrado contra Laio há tempo correspondeu à predição oracular” (SÓFOCLES, 1998, 1. 1016-1018), porque esta dizia que um filho de Jocasta mataria o próprio pai, e, tendo, como julgava, exterminado o filho, e morto o rei depois disso, não poderia ter um filho de Jocasta matado o pai, de sorte que o oráculo revelava-se errado (SÓFOCLES, 1998, 1. 1015-1022). A conclusão de Jocasta não podia ser mais ameaçadora para o sistema: “de hoje em diante, não mais olharei à esquerda ou à direita em busca de presságios" (SÓFOCLES, 1998, 1. 1013-1024). É nesse momento que a narrativa trágica finca a cunha a que se referiu, noutros termos, no início do parágrafo.

Trata-se, como se disse, da fala do coro. Os argumentos podem ser acompanhados em síntese. As leis são divinas (SÓFOCLES, 1998, 1. 1128-1140). 12 Mesmo os reis não podem ufanar-se de ser seu fundamento e o máximo que obtêm é orgulho (SÓFOCLES, 1998, 1. 1141-1150). Nesse contexto, o coro declara que "o homem que nos atos e palavras se deixa dominar pelo vão orgulho sem recear a obra da justiça e não cultua propriamente os deuses está fadado a doloroso fim” (SÓFOCLES, 1998, 1. 1051-1055). O coro continua argumentando que, achados em crime, não se pode deixar os homens a salvo dos "divinos dardos" (SÓFOCLES, 1998, 1. 1162), porque, se for assim, desacreditadas dos deuses, as pessoas deixarão de ir aos lugares sagrados (SÓFOCLES, 1998, 1. 1154-1171). Não nos percamos, julgando que o coro fale de crimes quaisquer, genéricos. Não, o coro está se referindo especificamente ao crime de que trata a própria tragédia:

Deus todo poderoso, se mereces teu santo nome, soberano Zeus, demonstra que em tua glória imortal não és indiferente a tudo isso! Desprezam os oráculos ditados a Laio, como se nada valessem; Apolo agora não é adorado com o esplendor antigo em parte alguma; a reverência aos deuses já se extingue. (SÓFOCLES, 1998, 1. 1072-1080).

${ }^{12}$ Cf. Kane (1975) p. 199-200. 
É realmente muito estranho o conteúdo dos últimos três versos ${ }^{13}$. Em nenhum outro lugar da tragédia se diz que vai se extinguindo a reverência aos deuses. Pelo contrário, em Édipo Rei, deles se fala o tempo inteiro. Todavia, aceitemos a lição de Vernant e Vidal-Naquet e, dando o procedimento por difícil, ignoremos a curiosidade por saber o que isso teria a dizer sobre o horizonte de produção da narrativa. Tampouco nos perguntemos quanto anos se contam entre a encenação de Édipo Rei e a execução de Sócrates, muito menos sobre a semelhança entre a conclusão do coro e as acusações que se arrostaram ao filósofo gravemente acusado. Ignoremos tudo isso. Mas não deixemos passar o texto em si. Para o coro, a tentativa de Édipo e de Jocasta de fugirem deliberadamente ao destino estabelecido pelos oráculos, como se eles "nada valessem" (SÓFOCLES, 1998, 1. 1078) é o motivo para daí se saltar para uma conclusão que, salvo melhor juízo, extrapola os limites da narrativa: "Apolo agora não é adorado com o esplendor antigo em parte alguma; a reverência aos deuses já se extingue” (SÓFOCLES, 1998, 1. 1078-1080). No fundo, essa é a preocupação do coro: "a reverência aos deuses já se extingue”. E, da mesma forma como, para Creonte, crer nos deuses é submeterse a eles, para o coro, reverenciar os deuses é, diferentemente do que Édipo e Jocasta tramam exatamente agora, submeter-se ao destino que os deuses traçam. Édipo e Jocasta “desprezam os oráculos ditados a Laio” (SÓFOCLES, 1998, 1. 10761077) - “a reverência aos deuses já se extingue” (SÓFOCLES, 1998, 1. 1080). Reverenciar os deuses é submeter-se a eles, diz o coro. Crer nos deuses é submeterse a eles, diz Creonte. O problema de Édipo Rei é justamente esse: a insubmissão dos homens aos deuses.

Mais tarde, "lento e triste" (SÓFOCLES, 1998, 1. 1392), o mesmo coro dirá que "com teu destino por paradigma [...] Édipo, julgo impossível que nesta vida qualquer dos homens seja feliz" (SÓFOCLES, 1998, 1. 1398-1401). A própria tragédia é encerrada com as palavras do corifeu, que insta os tebanos a que não julguem feliz um homem antes que ele tenha encerrado a sua vida "sem jamais ter provado o sabor de qualquer sofrimento" (SÓFOCLES, 1998, 1. 1802-1810)14.

\footnotetext{
13 A passagem que se acaba de sintetizar é dada como uma das mais discutidas da literatura grega, com variadas interpretações, o que, naturalmente, suscita a máxima prudência na aproximação. Cf. Scodel (1982) p. 214.

14 A citação direta encontra-se na última linha da tragédia.
} 
Corre-se o risco de tomarem-se isoladamente essas duas declarações, assumindo que o tema da tragédia seria a infelicidade inerente à vida do homem. A declaração de que nenhum edipiano homem logrará encontrar felicidade na vida precisa ser lida à luz da última declaração, aquela que alerta os tebanos quanto ao fato de que somente após reveladas as teias invisíveis do roteiro estabelecido pelos deuses para a vida dos homens é que se revelam tais paradigmáticos desgraçados. Enquanto vivo, e mesmo enquanto se julgando feliz, como vivo e se julgando feliz estava Édipo (SÓFOCLES, 1998, 1. 1492-1505)15, nenhum homem pode ser considerado feliz, porque ele não sabe o que lhe espera no destino prescrito pelos deuses. Não se trata de uma roleta, em que a alguns cabe a felicidade, a outros, não. Não se trata do acaso. Não se trata, tampouco, do arbítrio humano. Nada que Laio, Jocasta, o escravo e Édipo fizeram mudou um milímetro “os oráculos ditados a Laio" (l SÓFOCLES, 1998, 1. 1076-1077). Trata-se dos deuses. Deles depende a vida dos homens. Deles, e de mais ninguém. Deles, e de mais nada. Compreende-se que, para a mentalidade moderna, soe incompreensível tal declaração (BARSTOW, 1912). A tragédia de Édipo é justamente essa: os deuses reservaram a ele um destino desgraçado, que nenhum homem imaginaria para si e desejaria sequer para seus inimigos. E, porque os deuses assim fizeram, nada houve que pudesse ser feito para evitar o que estava decidido. "Quando Édipo mata seu pai e se casa com sua mãe sem saber ou desejar, ele é o joguete de um destino imposto a ele pelos deuses mesmo antes de seu nascimento" (VERNANT; VIDAL-NAQUET, 1990, p. 77, tradução nossa). ${ }^{16}$ Por isso, nem mesmo o conluio dos homens se pôs à altura de interpor-se ao desígnio dos deuses, porque, como sabia desde o início esse desgraçadamente infeliz Édipo, vítima dos deuses, “ninguém detém poder bastante para constranger os deuses a mudar os seus altos desígnios. ” (SÓFOCLES, 1998, 1. 333-335).

Em síntese, independentemente dos detalhes de cena, e mesmo independentemente do fato de que, neste caso, trata-se de um destino desgraçadamente triste, o enredo de Édipo Rei gira em torno da declaração

${ }_{15}$ Édipo achava que havia encontrado a felicidade.

${ }^{16}$ When Oedipus kills his father and marries his mother without knowing or wishing it, he is the plaything of a destine imposed upon him by the gods even before his birth. 
teológica de que nada pode ser feito, por absolutamente ninguém, que chegue a alterar o destino divino traçado para os seres humanos.

\section{José como tragédia}

“A história de José é uma das mais dramáticas e complexas narrativas bíblicas.” (LEVINSON, 1997, p. 270, tradução nossa). 17 “O tema principal é José e seu destino.” (GUNKEL, 1997, p. 381, tradução nossa, e no caso de parecer a algum leitor que a opinião de Gunkel encontra-se um pouco distante demais da efervescência acadêmica contemporânea, registra-se que há quem hoje fale tanto de "Destino de José” (MILLGRAM, 2012, p. 217, tradução nossa) ${ }^{18}$, quanto de que "Há uma inevitabilidade para sua tragédia” (MILLGRAM, 2012, p. 217, tradução nossa) ${ }^{19}$. Como centro nervoso de um enredo trágico, bem ao estilo de Édipo Rei, o referido “destino" de José foi objeto de inspiração de "três tragédias" (SIERHUIS, 2010, p. 27, tradução nossa). ${ }^{20}$, no século XVII. Fruto de sua "fascination with Greek tragedy" (GROOTES; SCHENKEVELD-VAN DER DUSSEN, 2012, p. 2) e "inspired by the example of Sophocles" (GROOTES; SCHENKEVELD-VAN DER DUSSEN, 2012, p. 3), Joost van den Vondel compôs Joseph in Dothan e Joseph in Egypten (1640). Tais peças de van den Vondel foram chamadas de "the three Old Testament tragedies” (PARENTE, 1987, p. 110). A percepção de José como tragédia é realmente elogiável. Embora se julgue que o termo tragédia componha o título da peça apenas pela razão de que fora composta em cinco atos, um século antes, Miguel de Carvajal já havia composto sua Tragedia Josephina (MCGAHA, 1998), a qual, à luz da atenção que, no teatro, a história de José recebeu desde o século XIII (MCGAHA, 1998, p. 9-12), sob nenhuma hipótese pode ser considerado um caso isolado. Séculos depois, sensivelmente mais próximo de nós, narrando as cenas iniciais da história de José (Gn 37), Longrace pode dizer que “o resto do capítulo se move com a inevitabilidade de uma tragédia grega" (LONGACRE, 2003, p. 42, tradução nossa). ${ }^{21}$ Tenha-se em mente, todavia, que dizer que a própria narrativa

${ }^{17}$ The story of Joseph is one of the most dramatic and complex of biblical narratives.

${ }_{18}$ Joseph's fate.

${ }^{19}$ There is an invevitability to his tragedy.

${ }^{20}$ Three tragedies.

${ }^{21}$ The rest of the chapter moves with the invevitableness of a Greek tragedy. 
funciona como uma tragédia não é a mesma coisa que dizer que o fato de os irmãos terem interpretado errado os sonhos de José teria levado à tragédia familiar: "esta interpretação errônea levou à tragédia, porque impeliu os irmãos de José a destituílo do papel de liderança atribuído por seu pai.” (CHIEL, 2005, p. 5, tradução nossa). ${ }^{22}$ Por exemplo, a despeito de informar que Sedmark lê a história de José “com as marcas da tragédia.” (QUASH, 2011, p. 26-27, tradução nossa) 23, Quash, como ele mesmo diz, prefere "ver esta história como menos trágica do que Sedmark" 24 (QUASH, 2011, p. 26-27, tradução nossa). ${ }^{25}$ Em campos disciplinares diferentes, a percepção geral de Carvajal, de van den Vondel, de Longrace e de Sedmark é preferível à de Chiel e de Quash, porque até há uma "tragédia" na história de José, mas a própria história constitui um exemplar do gênero tragédia do tipo Édipo Rei.

Constituindo "um tipo de literatura que é distintiva em Gênesis" (BRUEGGEMANN, 1982, p. 107, tradução nossa) ${ }^{26}$, o que se pode chamar de José no Egito encontra-se registrado em Gn 37-50. Ainda que se possa afirmar que contam-se "nos três círculos narrativos Gn 10,1-25,11; 25,12-36; 37-50, a história de três gerações de famílias dos patriarcas de Israel, Abraão e Sara, Isaac e Rebeca, Jacó e Lia/Raquel na terra da promissão. ” (ZENGER, 1998, p. 47), a rigor (Gn 37, 50) trata desproporcionalmente mais da história de José do que qualquer outra coisa, conquanto a história de José possa servir como cenário para tudo o mais. Quanto à história de José, há pelo menos cem anos que, como se viu acima, “o principal tema de José é deu destino." (GUNKEL, 1997, p. 381).

A partir de Gn 37, inclusive, a história de José pode ser sinteticamente narrada nos seguintes termos (cf. LONGACRE, 2003, p. 41-51). José revela aos irmãos um primeiro sonho (Gn 37,5$)$, no qual os feixes que plantava erguiam-se, e diante do qual se prostraram os feixes de seus irmãos (Gn 37,6-7). Contrariados,

${ }_{22}$ This misinterpretation led to tragedy because it impelled Joseph's brothers to depose him from the leadership role assigned by his father.

${ }_{23}$ With the marks of tragedy.

24 Registre-se que o pesquisador lamenta profundamente não ter tido acesso direto à obra que Quash menciona: Kothgasser, A.; Sedmark, C. (2008). Os comentários que Quash faz a respeito das declarações de Sedmark aproximam-no substancialmente da percepção que aqui se defende.

${ }_{25}$ To view this story as less tragic than Sedmark.

${ }^{26} \mathrm{~A}$ kind of literature wich is distinctive in Genesis. 
estes lhe perguntam se é seu desejo reinar sobre eles (Gn 37,8). A animosidade aumenta, quando José lhes narra um segundo sonho: o Sol, a Lua e onze estrelas se prostravam diante dele (Gn 37, 9). O sonho foi narrado tanto ao seu pai quanto aos irmãos, que se aborreceram ainda mais ( $\mathrm{Gn}$ 37, 10-11). Já agora perceptível, o final da narrativa acentuará o caráter oracular desses sonhos.

Na sequência da narrativa, tomados de contrariedade em relação ao irmão, deliberadamente decidem dar um fim às pretensões de José. Expediente tanto carregado da mesma incompetência tática observada em Édipo Rei, mas inexoravelmente universal nesse tipo de narrativa, os irmãos de José simulam sua morte, que de fato não ocorre, e, a depender da versão, vendem-no ou o deixam para morrer em uma cova (Gn 37, 12-35). De qualquer forma, José acaba sendo vendido a Potifar, eunuco do faraó egípcio (Gn 37, 5-6). Aparentando ser cada vez mais impossíveis os sonhos de José, escravo no Egito, o filho de Jacó enfrenta problemas com a esposa de seu comprador, e acaba sendo lançado na prisão (Gn 39, 1-20a).

Na prisão, as chances de seus sonhos se tornarem realidade parecem cada vez menores. No entanto, a história de José começa a sofrer uma guinada. Porque desvenda sonhos na prisão (Gn 39, 20b-40,23), a notícia chega a Faraó (Gn 41, 114). José desvenda agora um sonho de Faraó ( $\mathrm{Gn}$ 41, 14-36) e acaba sendo instalado por este como administrador da política alimentar do Egito (Gn 41, 3756).

Nesse ponto, inicia-se a série narrativa que se coroará com o cumprimento dos oráculos - isto é, os sonhos. Primeiro, em busca de pão, dez dos filhos de Jacó dirigem-se ao Egito ( $\mathrm{Gn}$ 41, 57-42,6), onde têm um primeiro encontro com José, sem, todavia, lograrem identificá-lo como tal ( $\mathrm{Gn}$ 42,6-24a). José mantém cativo um dos irmãos, e ordena que os demais retornem para casa e voltem com o irmão mais novo, que permanecera com o pai (Gn 42,24b-38). Quando Jacó permite que retornem para o Egito (Gn 43,1-25), ainda incógnito, José os recebe em sua casa, e eles se prostram diante do administrador da política alimentar egípcia: "se 
prostraram diante dele até o chão." (Gn 43, 26). Depois de comerem e beberem e confraternizarem (Gn 43, 27-34), José manda que seus homens encham os sacos com trigo, mas coloquem a sua taça de prata na carga de Benjamim (Gn 44, 1-2). Quando os irmãos estão retornando para casa, os homens de José interceptam-nos, a taça é encontrada na carga de Benjamin e este é recolhido como escravo (Gn 44, 13).

A despeito de o cumprimento do oráculo já ter-se plasticamente dado, quando os irmãos se prostram diante de José, a narrativa caminha para seu verdadeiro clímax, porque, quando o fizeram, eles ainda não sabiam de quem se tratava de fato. Com o menor acusado de roubo e preso, os irmãos retornam para a cidade, e vão à casa de José $(\mathrm{Gn} 44,14)$. Após uma comovente cena, em que Judá se oferece para ficar no lugar de Benjamin (Gn 44,15-34), José finalmente se revela aos irmãos (Gn 45,1-2). A família se reconcilia e o próprio pai, finalmente, se dirige à companhia do filho, até então dado como morto (Gn 45,3-47,12). No fim da história, os dois sonhos de José se cumprem.

Disse-se acima que, na economia da história de José, os dois sonhos têm função oracular (GUNKEL, 1997; BRUEGGEMANN, 1982). Comprova-o as declarações postas na boca de José, depois que se revelou aos irmãos. Quando José se revela aos irmãos, procura imediatamente tranquilizá-los, dizendo que, para todos os efeitos, não foram eles, seus irmãos, os responsáveis pelo seu destino, mas, nas suas palavras, "foi Deus quem me enviou." (Gn 45,5), e, novamente, "não fostes vós que me enviastes aqui, mas Deus" (Gn 45,8a). Segundo ainda suas declarações, "Ele (Deus) me promoveu a Pai de Faraó, senhor de toda a sua casa e regente de toda a terra do Egito" (Gn 45,8b). No primeiro sonho, os irmãos, e no segundo sonho, tanto estes quanto seu pai e sua mãe se curvavam diante dele. A cena significa, em termos oraculares, o que ocorrerá mais tarde, quando, em dois sentidos diferentes, os irmãos realmente se curvam diante de José: quando, sem saber que era José, se curvam ao superintendente geral do Egito, e, posteriormente, quando reconhecem-no como seu irmão e sabem que é ele o "regente sobre toda a terra do Egito" (Gn 45,26). Quando, na economia narrativa, José afirma que foi 
Deus quem o levou para o Egito, fazendo-o assumir a posição política que assumiu, "notificai a meu pai toda a importância que tenho no Egito." (Gn 45,13), isso implica em concluir-se que aqueles sonhos faziam parte da determinação divina: tanto o cumprimento dos sonhos quanto os próprios sonhos são de responsabilidade divina. O oráculo é divino, e a garantia da realização do oráculo igualmente o é.

Nesse sentido, está posta a narrativa trágica, no sentido em que Édipo Rei se configura. A despeito da maior sofisticação relativa de Édipo Rei, as duas peças literárias compartilham o mesmo esquema. No início de tudo, um oráculo, que anuncia a determinação inexorável dos deuses, no caso grego, do deus, no caso judaico. Nas duas peças literárias, com a tentativa deliberada de fugir à determinação oracular divina, personagens se lançam a operar táticas diversas. No caso grego, três personagens tentam evitar a desgraça, e, tentando-a, no fundo a garantem. No caso de José, a mesma coisa: é o ato de pretender a morte de José que faz com que os irmãos acabem encaminhando-o ao Egito, e se José pode dizer que não foram eles, mas Deus que o fez, isso apenas quer dizer que, na economia desse tipo de narrativa, bem como nos termos da abordagem aqui aplicada, nada que os homens façam é de fato ação desses homens, mas opera apenas o cumprimento da determinação divina, tenham disso ou não consciência os personagens. É curioso que Brueggemann descreva exatamente esse esquema que se acaba de traçar, e, todavia, não infira daí a conclusão de que se esteja diante de um modelo trágico do tipo Édipo Rei: “os caminhos de Deus estão em ação, independentemente das atitudes ou ações humanas.” (BRUEGGEMANN, 1982, p. 289, tradução nossa). ${ }^{27}$ Além disso, pode-se até contemplar providência divina no enredo (HAY, 2012, p. 31), mas, quando se está informado de que tal providência divina estava desde o início pré-determinada, então se deve considerar que, para todos os fins, nesse tipo de história, ou, mais tecnicamente, nesse tipo de gênero literário - tragédias do tipo Édipo Rei - o comportamento dos atores é irrelevante: tudo que deve acontecer vai acontecer, porque assim determinaram os oráculos. Se

${ }_{27}$ The ways of God are at work, regardless of human attitudes or actions. 
providência há, é no sentido de garantir que nenhum dos desígnios divinos se frustre.

Ainda nas duas narrativas, a história se desenvolve de sorte a dar a impressão de que os oráculos malograram. José é lançado à cova ou vendido, e, seja como for, acaba escravo no Egito. Piora sua situação quando, de escravo, cai ainda mais, sendo lançado às masmorras. Não importa se, em Édipo Rei, quanto mais aparentemente feliz seja a condição de Édipo, mais desgraçada de fato seja sua situação, e, que, ao contrário, na narrativa de Gênesis, quanto mais desgraçada pareça a condição de José, mais afortunado de fato ele o seja, porque isso o aproxima cada vez mais de sua glorificação oracular. O que importa é perceber que ambas as narrativas levam a história até um ponto em que as vidas em jogo parecem ter se dirigido na direção contrária ao indicativo oracular e, de súbito, a situação se reverte justamente na direção do inexorável cumprimento da determinação divina. No campo narratológico, isso nada tem a ver com o destino feliz ou triste, afortunado ou desgraçado, da personagem-chave. Não vem ao caso que os oráculos anunciem a desgraça radical de Édipo, enquanto anunciam ao mesmo tempo a graça de José. Isso não tem nada a dizer sobre a estrutura em si desse tipo de narrativa, cujo eixo de sentido gira em torno não da felicidade ou da infelicidade dos homens, mas da incapacidade que têm de mudar seu destino, definitivamente determinado pelos deuses. Nem Laio, nem Jocasta, nem o escravo da coroa, nem o mensageiro, nem Édipo, nem os irmãos de José, ninguém tem o poder de mudar a deliberação dos deuses, que, na economia da tragédia, vai expressa nos oráculos.

A história de José é diametralmente oposta à de Édipo: este, o mais desgraçado dos homens; aquele, o mais afortunado. No entanto, as duas histórias são exatamente iguais: Édipo e José são vítimas dos desígnios divinos, e qualquer tentativa, deles mesmos ou de terceiros, de tentar alterar o rumo dos caminhos já desde sempre traçados é absolutamente inútil. José é uma tragédia do tipo Édipo Rei. José é uma tragédia que compartilha com Édipo Rei sua teologia e teodiceia. O fato de serem os contextos teológicos tão distantes - a Grécia polilátrica e a Judá 
monolátrica - apenas novamente ilustra o fato de que, diante da estrutura discursiva e da ontologia-teológica pressuposta, os conteúdos específicos são irrelevantes: os homens podem se arvorar em agentes determinantes de sua vida, mas, para todos os efeitos, por mais que se esforcem, e por mais que as aparências circunstanciais levem-nos à crença de que bem se sucederam seus esforços de escapar à vontade dos deuses, é esta vontade e apenas esta vontade que se cumpre, sempre.

Édipo Rei e José são expressões narrativas do mesmo gênero e subgênero literário: são, ambas, tragédias, e, ambas, tragédias do mesmíssimo tipo. Não se deve descartar que a história de José pressuponha a circulação de Édipo Rei no contexto de seu horizonte de produção. Mas não é essa questão que aqui interessa. Interessa outra questão: assim como, em Édipo Rei, o enredo é absolutamente artificial, e mesmo falso, da mesma forma, em José, o sucesso do enredo depende significativamente na incompetência tática e estratégica dos agentes que são postos a tentar evitar o destino inexorável dos deuses. Nos dois casos, o oráculo sofreria malogro irrecuperável, se, em um caso, Édipo, e noutro, José, tivessem sido simplesmente executados aqui e agora. Como Girard (2008) sabe, as intenções dos autores estão condicionadas por seu projeto narrativo, de sorte que Sófocles e o autor de José não podem fazer o que a lógica circunstancial imporia: Laio e Jocasta afogarem o recém-nascido na bacia do parto, e os irmãos terem efetivamente executado José. Todavia, a tese desse tipo de tragédia - o destino é inexoravelmente ditado pelos céus - só pode ser provada por meio de artifícios constrangedores: Laio e Jocasta terceirizarem a execução da criança, o terceirizado, por sua vez terceirizar a encomenda, e, na outra ponta, Édipo, fugido de um oráculo que lhe dava por assassino, a primeira coisa que faz é assassinar alguém, os irmãos chegarem a simular a morte do irmão, e não de fato o matarem. Se for permitida ironia, para serem quem são, os deuses precisam de incompetentes. No entanto, a questão é outra: o roteiro depende desses desvios, sem os quais não há Édipo Rei nem José. 
Na verdade, a graça das duas histórias exige que o auditório não avalie o enredo e, ainda mais, as estratégias adotadas pelos personagens. Quase como se estivéssemos diante de um espetáculo religioso, do qual se deve participar sem analisar, sem avaliar, mas entregando-se em nível psicológico total, Édipo Rei e José não funcionam se, no meio da apresentação, você grita que Laio e Jocasta devem deixar de ser incompetentes, e que matem ali mesmo a criança, ou que os irmãos deixem de teatro e, efetivamente, executem José. Se a coroa tebana e os filhos de Jacó agissem como Abel agiu, não haveria narrativa. No caso de Abel, não faz nenhuma diferença ele matar ou não matar o irmão. Isso não muda em nada a economia e a mensagem da narrativa: aborrecido pela preterição de que é objeto, ira-se com o irmão. Matando-o ou não, está dada a mensagem. Caim e Abel não é uma tragédia, quanto menos uma tragédia do tipo Édipo Rei. No caso do tipo de narrativa em que consistem Édipo Rei e José, todavia, os heróis não podem ser mortos, porque, se forem, acaba-se ali mesmo a história, e os oráculos falham, como Jocasta julgou terem falhado os fatídicos que diziam respeito ao marido. Se pretendem dizer alguma coisa a respeito da vida e da realidade, Édipo Rei e José precisam falsificar a vida e a realidade. Mais: precisam que o auditório seja cúmplice dessa alienação. Somente quem quer que a retórica de que os deuses determinam a vida humana se aplique à vida dos homens há de contentar-se com um roteiro tão falsamente sustentado.

Por que a insistência nesse ponto? Por que a denúncia da necessidade da cumplicidade necessária entre o auditório e a tragédia? Por uma razão muito específica. Há, na mesma Bíblia Hebraica, uma narrativa que, em termos retóricos, funciona como uma "reinscrição transgressiva" da tragédia de tipo Édipo Rei. Para todos os fins, ela se disfarça de tragédia. Compõe-se aparentemente como tragédia, funciona até quase seu derradeiro fim como tragédia, e, quando se julga que, afinal, o roteiro trágico venceu, a própria narrativa subverte o enredo, o tipo, denuncia a falsidade dos argumentos e aponta a causa da aparente harmonização entre o enredo trágico e a vida: a cumplicidade do auditório. Trata-se de Cântico dos Cânticos. 


\section{Cântico dos Cânticos como contratragédia}

Cientes de que "há consenso em relação ao Cântico dos Cânticos em apenas duas questões: trata do 'amor' e sua poesia é requintada." (BAKON, 1994, p. 211, tradução nossa) ${ }^{28}$, conquanto apresentada por renomados especialistas como um mosaico de poemas independentes e sem unidade que não o tema do amor e do desejo (KEEL, 1994; GOITEIN, 2000; CAVALCANTI, 2005), assume-se que a obra Cântico dos Cânticos pode ser lida como uma composição orgânica (BARBIERO, 2011). Já se viu que, em relação ao "coro", "a similaridade com a tragédia grega é óbvia." (BARBIERO, 2011, p. 16, tradução nossa) ${ }^{29}$, e que o fato de Cântico dos Cânticos estruturar-se na forma de diálogos coloca a peça literária "desta forma também chegando perto do mundo do teatro grego" (BARBIERO, 2011, p. 16, tradução nossa). ${ }^{30}$ Ainda que o autor que tenha apontado tais semelhanças com a tragédia grega declare que "Considerá-lo um drama clássico não convence" (BARBIERO, 2011, p. 160, tradução nossa)31', preferindo classificá-lo como um "trabalho lírico com elementos dramáticos." (BARBIERO, 2011, p. 17, tradução nossa) 32, como se verá, a identidade trágica da composição vai além do paralelo com os coros das tragédias gregas. Em termos de sofisticação de estratégia narrativa, Cântico dos Cânticos supera Édipo Rei. Na tragédia grega, o fio narrativo se desdobra sempre no presente, e o passado é jogado em cena por meio de rememorações feitas aqui e agora, mas não encenadas, controladas pelo diálogo que se tratava, como estratégia de presentificação do passado. Em Cântico dos Cânticos, representando a maior porção do fluxo narrativo, os momentos de passado são encenados como que aqui e agora, o que exige uma extraordinária criatividade narrativa. Por força de que pode ser inusitada a declaração, assume-se que se faça necessária a apresentação do enredo em dois registros. Primeiro, sua apresentação linear, e, depois, a explicação de como esse roteiro linear está construído narratologicamente.

\footnotetext{
${ }^{28}$ There is consensus regarding the Song of Songs on only two issues: it deals with 'love' and its poetry is exquisite.

${ }_{29}$ The similarity to Greek tragedy is obvious.

${ }^{30}$ In this way too coming close to the world of the Greek theatre.

${ }^{31}$ To consider it as a classical drama are not convincing.

${ }^{32}$ Lyrical work with dramatic elements.
} 
Em termos de roteiro, Cântico dos Cânticos conta a história de uma mulher que decide assumir seu destino em suas próprias mãos, o que implica em negociar com um companheiro o compartilhamento de sua utopia. Trata-se de mulher que, desde criança, esteve submetida aos mandos e desmandos dos irmãos, tendo cuidado dos olivais da família até o dia em que decidiu furtar-se ao roteiro sociocultural a que sua existência de mulher estava destinada. O momento chave dessa decisão está vinculado ao despertar do desejo. Em determinada ocasião, ela avista um pastor que passa nos limites dos olivais. Elemento chave do enredo, porque é a ele que se refere o oráculo que rege a estrutura trágica da narrativa, o desejo que irrompe no corpo da heroína subverte não apenas os limites socioculturais impostos, mas mesmo os limites físicos, e a mulher se põe à procura do pastor. Encontra-o, e arranca dele um pacto de cumplicidade, que se traduz na promessa dele de dedicar a ela a exclusividade de sua admiração e seu desejo.

Uma vez que, quando tangenciam a nervura do real, as utopias tendem a travar, os irmãos se revelam um obstáculo à sua emancipação por meio do casamento. A despeito da declaração de que "a canção não se preocupa tanto com as consequências econômicas e sociais do casamento para famílias específicas" (MUNRO, 1995, p. 73, tradução nossa) 33, os planos da heroína interferem diretamente na economia familiar. Decidida, todavia, ela enfrenta os irmãos, bem como à covardia do desejado, que, à ameaça dos irmãos dela, foge. Pela segunda vez, ela vai atrás dele, encontra-o, trá-lo para casa, e arranca dele e deles o casamento emancipatório que vai julgando estar construindo. A cena do casamento ocupa a maior porção do texto, e é uma das mais belas páginas da literatura erótica 34.

As expectativas da mulher se frustram. A despeito de ter-se comprometido por meio de uma promessa de exclusividade, seu agora marido amplia sua relação para a instituição do concubinato. Outras esposas são introduzidas na relação. Contrariada, a mulher se tranca em seu quarto, disposta a não permitir contato

33 The Song is not so much concerned with the economic and social consequences of marriage for particular families.

34 Para o tema da presença do discurso erótico em Cântico dos Cânticos, cf. Black (2009, p. 11-20); cf. ainda Bloch; Bloch (1995). 
com aquele que a traiu. Quando este tenta forçar a porta e entrar, o desejo toma inexoravelmente a "traída”, arrasta-a até a porta e obriga-a a abrir àquele que sua consciência, mas não seu corpo, sua utopia, mas não seu desejo, enxergam como traidor.

Ele não está mais. Foi embora. Pela terceira vez ela vai atrás dele. Encontrao. Discutem a relação. Ela pergunta se ele não a deseja mais. Ele diz que sim, que ela é amada e desejada. Ela pergunta então por que as outras esposas. Ele diz que ela não deve se comparar a elas, porque ela é a preferida dele. Ela pergunta então por que ele prometeu a ela ser só dela. Ele não tem mais alternativas a não ser dizer a ela que ele apenas fez o que é direito dos homens fazerem.

A narrativa se encaminha para o final. O elemento fundamental da tragédia - o “oráculo" - será apresentado agora. Trata-se da maldição divina, interposta às mulheres: mulher que é, ela é maldita, o desejo dela o impelirá ao seu homem e seu homem a dominará (Gn 3, 16)35. Da mesma forma que Laio, Jocasta, Édipo, o escravo e os irmãos de José tentaram fugir às determinações divinas, a heroína da - até aqui - tragédia de Cântico dos Cânticos pretendeu ser possível fugir à injunção que inexoravelmente regeria sua vida: construiria com seu homem uma relação fraterna, sem jogos de dominação. O desejo despertou nela a força para instalar a utopia, e ela julgou ter logrado êxito. Todavia, tudo se revela falso: ele mentiu. Ele a traiu. Ela quer romper a relação. Mas, ironia!, o desejo que a empoderou faz, agora, com que ela se submeta: ela deseja o traidor. Sua consciência a repele dele, mas seu corpo a impele a ele. Seu desejo impõe a ela que aceite a condição de apenas mais uma entre as mulheres dele. Ela capitula. Ele a domina. O oráculo vence. A mulher vive sob o peso da maldição divina, de sorte que seu próprio desejo a escravizará ao seu homem, e não há nada que ela possa fazer para evitar isso. Nem ele quer...

Terminasse assim a narrativa, Cântico dos Cânticos seria uma tragédia do tipo Édipo Rei e José. O oráculo $(\mathrm{Gn} 3,16){ }^{36}$ determina que o roteiro da vida da

35 Para a relação entre Cântico dos Cânticos e Gn 2-3, veja Kingsmill (2009).

${ }^{36}$ Para o fenômeno literário de intertextualidade entre Cântico dos Cânticos e Gênesis 3,16, veja Ribeiro (2014, p. 312-324). 
mulher consiste em desejar seu homem e ser dominada por ele. A heroína de Cântico dos Cânticos não quer esse destino para si. Quer outro. Literalmente, vai atrás dele. Movida pelo desejo, constrói sua utopia. Julga ter escapado do destino que cabe à mulher. Tudo parecia se encaminhar conforme sua estratégia, e, no entanto, quando ela se encontra no momento mais aparentemente feliz, eis que é golpeada tanto por seu próprio desejo quanto pelo próprio homem que ela deseja. Tragédia: o destino oracular do qual ela tentou fugir a captura em sua rede inexorável.

No entanto, a narrativa não acaba assim. Em uma das cenas mais extraordinárias da Bíblia Hebraica, uma das mais espetaculares mesmo, a amada dança para o seu homem, que, assistindo-a em seus rebolados e requebrados de odalisca, é tomado a tal ponto pelo desejo que se levanta de onde está, vai até ela, agarra-a, beija-a, e dá a ela a ocasião de destruir o primeiro argumento do argumento trágico: o desejo que a toma é o mesmo desejo que o toma, de sorte que não há nada de errado com o desejo dela, já que o oráculo não trata o desejo do homem como objeto de maldição. O desejo não é maldito. O desejo é bom.

O oráculo está ferido, mas não morto. Porque resta uma inapelável situação trágica: se nada há de errado com o desejo da mulher, de sorte que o oráculo estava errado ao dizer que o desejo dela a impele a ele e ele a domina, por que, no final das contas, ele realmente a domina? Por que ele fez valer o desejo dele, e não o dela? Por que o desejo dela a levou aonde ela não queria? A resposta da heroína soa com lucidez abissal: ele a dominou, porque ele não foi fraterno. Não há nada de errado com meu desejo, ela diz, e arremata: se ele não tivesse sido o canalha que foi, o oráculo estaria destruído, porque meu desejo permaneceria aqui, ele não me dominaria, e estaríamos, os dois, a sentir o perfume das mandrágoras... no jardim... Ele foi meu amante, meu noivo, meu amado, mas não foi meu irmão. Ele até empregou o termo "irmã" (MUNRO, 1995), quando se dirigia a ela, mas ser de fato como que um irmão para ela, nunca. Ele, e ninguém mais, poderia ter comprovado que o oráculo é uma fraude, e só funciona por meio da cumplicidade dos atores. Eu só estou na situação em que estou porque meu homem me coloca na situação em 
que me coloca. Não há maldição: há um jogo político-social, em que, de um lado, os operadores da teologia oracular promovem os discursos mitoplásticos, de outro, os cúmplices sociais - os homens daquela cultura - incorporam os papeis, e, no lado mais fraco do jogo, elas, as mulheres, pagam o preço. Os operadores da teologia oracular e a sociedade patriarcal garantem a ilusão da veracidade dos oráculos. Não há tragédia. Há engodo. Há cumplicidade. Não há teologia. Há política, ideologia, compadrio.

A narrativa de Cântico dos Cânticos é extremamente sofisticada. Em dois momentos fundamentais, o leitor é surpreendido com a revelação da verdadeira questão em jogo. No primeiro caso, trata-se da experiência de revelação própria da tragédia, já que o tipo de enredo que está em jogo é aquele em que os planos de autonomia da personagem são frustrados pelos desígnios do oráculo. No caso de Cântico dos Cânticos, isso corresponde àquele percurso narrativo em que a heroína opera sua estratégia de emancipar-se, seção que culmina com a longa cerimônia de casamento. O último momento dessa seção é Ct 5,1. No verso seguinte ( $\mathrm{Ct} 5,2)$, a reviravolta trágica já se operou, conquanto o leitor apenas paulatinamente disso se aperceba. Daí em diante, revela-se passo a passo a estrutura trágica do enredo, conquanto o leitor somente venha a estar totalmente inteirado de ser esse o caso no capítulo sete. De Ct 5,2 até o final do capítulo seis, a tragédia se consolida, mas permanecem em suspenso dois elementos estruturantes da obra: o estatuto oracular das condições de vida da heroína e sua reação em face da revelação de que seu homem a traiu.

No capítulo sete e início do oitavo, revelam-se os dois elementos. Que se trata do peso oracular sobre a vida da mulher revela-o o fato de a heroína inverter explicitamente (Gn 3,16) 37, de sorte que fica revelado o fato de que a chave de compreensão do roteiro é a leitura da vida da heroína como a atualização inexorável do destino de toda mulher que, maldita pelo deus, tem em seu desejo o operador inapelável de sua sentença teológico-judicial: sua submissão ao seu homem. Quanto à reação da heroína diante da revelação de seu estado oracular, no

${ }_{37}$ Cf. adiante. 
mesmo capítulo sete e início do oitavo, dá-se a saber que ela permanece com seu homem, nega o estado de maldição que supostamente lhe caracteriza e explica sua desconcertante condição de "submetida" pelo fato de que, adequando-se ao jogo político-social instalado na cultura, seu homem encene exatamente o papel que cabe ao macho submetedor no mitoplasma engendrado pelo establishment. Segundo a leitura da heroína, se, ao invés de submetê-la, seu homem a tivesse tratado como haviam combinado ambos, o mitoplasma se revelaria falso, e todo poder que o mitoplasma exerce em termos de controle social se dissolveria imediatamente. É exatamente o diagnóstico da heroína que destrói a fatalidade trágica em sua dimensão ontológico-teológica, o que é também ilustrado na narrativa como um todo pelo fato de a divindade jamais ser sequer nomeada ${ }^{38}$ : não há tragédia aí que não seja única e exclusivamente o conluio entre classe sacerdotal dominante e uma das classes dominadas, os camponeses machos, cuja moeda de negociação é o conjunto das mulheres. A crítica que se pode fazer à ingenuidade tática das personagens de Édipo Rei e José, quando se dá conta da incompetência daqueles que poderiam ter executado o herói antes que a situação fugisse ao controle imediato dos interessados, o que não é feito simplesmente porque os autores desse tipo de tragédia precisam dessa incompetência, a heroína desenvolve em Cântico dos Cânticos, mas não em termos de incompetência do seu homem, mas da denúncia de sua cumplicidade com a classe dominante: se não houvesse sua cumplicidade, não haveria tragédia. O oráculo de Édipo Rei depende da incompetência de Laio e Jocasta. Os sonhos divinos de José dependem da incompetência tática de seus irmãos. O destino trágico da heroína de Cântico dos Cânticos depende da cumplicidade pérfida de seu homem, mesquinha e egoisticamente capitulando diante dos interesses da classe dominante.

Para fins de explicitação, pode-se, brevemente, indicar a função retórica de cada seção de Cântico dos Cânticos (Ct 1,2-8,4) na economia da contratragédia que representa. Dados os marcos estruturais a que se fez referência, resulta que a narrativa está dividida em três seções. A primeira seção vai do prólogo até o trecho em que a heroína cuida ter logrado conquistar sua autonomia em face do destino

${ }^{38}$ A narrativa encerra-se em Ct 8,4. Os versos posteriores a esse são acréscimos redacionais. 
oracular reservado a todas as mulheres de sua cultura (Ct 1,2-5,1). A segunda seção vai das primeiras reações da heroína diante da traição de seu homem até a indisfarçável confissão deste de que tem direito de agir como todo homem de sua cultura pode agir (Ct 5,2-6,12). A terceira e última seção é constituída pelas duas respostas que a heroína arrosta à dimensão trágica de sua condição: seu desejo não é maldito e sua condição de mulher oprimida é resultado do conluio entre seu homem e a classe dominante ( $\mathrm{Ct} 7,1-8,4)$.

Em breve detalhamento, as três seções podem ser assim apresentadas. Quanto à primeira seção, o prólogo ( $\mathrm{Ct}$ 1,2-4) situa-se no presente narrativo imediatamente anterior ao capítulo sete. Conquanto a magistral narrativa contenha elementos suficientes para que uma inquietante suspeita paire sobre o leitor, a rigor apenas os personagens detêm as informações quanto à condição da heroína. No prólogo, ela já está submetida ao concubinato, já aceitou esta condição, expressa seu desejo pelo homem que já a traíra, e, em função das atenções dele, desperta as provocações de suas colegas de concubinato (Ct 1,1-4). Tais provocações são a deixa para que a heroína comece o longo percurso de memória de sua vida. Primeiro, explica sua condição estética como fruto da opressão de seus irmãos, ao mesmo tempo em que inicia a narrativa de sua estratégia de emancipação, o que se teria dado pelo fato de seu desejo ter sido despertado pela passagem de um pastor nos limites dos olivais da família (Ct 1,5-6). A heroína conta que, despertada de sua imobilidade sociocultural pelo desejo, buscou o pastor (Ct 1,7-8), encontrou-o e arrancou dele um pacto nupcial, baseado fundamentalmente na promessa de admiração e exclusividade (Ct 1,9-2,7). Rememora o dia em que, para desposá-la, o pastor comprometido foi até a casa dos irmãos, que o receberam ameaçadoramente, diante do que ele fugiu, o que fez com que ela mesma fosse atrás dele, o tomasse e o impusesse à família (Ct 2,8-3,5). Com todos os acontecimentos corroborando seus planos de emancipação, a longa cena de casamento é rememorada em detalhes: a heroína julga ter não apenas encontrado a alforria, mas a felicidade e a total satisfação de seus desejos (Ct 3,7-5,1). Termina a primeira parte. 
Na segunda parte, a tragédia cai pesada e inapelavelmente sobre o corpo e, sobretudo, a mente da heroína. A primeira cena, fundamental na economia do enredo, é narrada ainda pela heroína como memória (Ct 5,2-6,3). Tendo o seu homem deixado de cumprir a promessa de exclusividade, a heroína impede que ele entre em seu quarto. Quando ele força a porta, o desejo irrompe vulcanicamente das entranhas da trágica criatura. A partir daí, não é mais a estratégia consciente que controlará seus passos, mas o desejo, que, exatamente como disse o oráculo, a impelirá para seu homem, que a dominará. Com efeito, ela se levanta para deixar que ele entre no quarto, mas, quando abre a porta que ele forçara, ele não se encontra mais. A heroína vai em busca do esposo, que se fora, sofre violência por parte dos guardas da cidade, e, inquirida pelo coro sobre quem é afinal tão especial homem a ponto de ela encontrar-se em tal estado por causa dele, descreve-o em termos de objeto de seu desejo. O coro, composto pelas concubinas, oferece-se para ajudá-la em sua busca de seu homem, e, então, ela revela que ele a traiu.

A cena seguinte (Ct 6,4-12) resume-se ao encontro da heroína e do esposo recém-encontrado. Ainda se trata de memórias narradas. O diálogo entre a heroína e seu homem constitui-se de crescente tensão, cuja chave é a situação de concubinato em que o marido a colocou. Ele não a ama mais? Ama, e ela é desejável e formosa. Se ela é desejável e formosa, então por que ele precisa de outras mulheres? Uma tolice ela se preocupar com isso, porque ela é a preferida, e as demais não passam de figuras secundárias. Mas você me prometeu ser meu único homem e ser eu sua única mulher!... Não vem ao caso: todo homem tem direito a ter quantas mulheres queira e possa. É assim que as coisas são. Encerra-se a segunda parte. A essa altura, o leitor ou auditório não sabe exatamente que resposta a heroína dará à declaração crua que acaba de ouvir, e, para todos os fins, está diante de uma tragédia: a heroína tentou se livrar do destino das mulheres de sua cultura, conquistou a promessa de um homem que lhe garantiu dar tratamento especial, casou-se com ele e, quando julgou ter conquistado sua liberdade e autonomia, vê-se metida na mesma eterna posição de peça de um jogo dominado pelos homens. 
Na terceira e última seção (Ct 7,1-8,4), todas as revelações são apresentadas. A narrativa sai do nível das memórias da amada, retornando ao presente narrativo, coetâneo ao prólogo. Revela-se a condição oracular da vida da heroína, submetida que estivera o tempo todo às injunções da maldição divina. Em termos narrativos, essa informação se dá por meio da reversão que a heroína faz de (Gn 3,16$)$, intertextualmente atualizado em Ct 7,11: “e para mim é o desejo dele”. Ao mesmo tempo, contudo, em que o leitor finalmente é certificado de que se tratava, o tempo todo, de uma condição trágica, a heroína rasga o roteiro e destrói a fatalidade encomendada pelo mitoplasma político-teológico. Primeiro, ela dança sensualmente para seu homem, que, tomado de desejo e arfando de paixão, agarraa e beija-a, perdido... Enquanto agarrada por ele, a heroína se volta ao leitor e declara que ela é de seu amado (ela aceita o cativeiro)39, mas que, tanto quanto o desejo dela, que o leva a ele, o desejo dele igualmente o leva até ela, é o que se vê, literalmente, ali e então, de sorte que, um pelo outro, não há maldição aí, senão corpos em fogo, desejos ardendo. A heroína destrói o mitoplasma, reduzindo o jogo da paixão à efervescência mútua dos corpos. Tanto quanto o leitor ou a plateia, a heroína, todavia, sabe que destruir o mitoplasma não modifica sua situação - ela continua vítima da traição de seu homem e presa a ele por seu desejo. Se isto não é atualização oracular de uma maldição divina, então é o quê? Trata-se, ela diz, da falta de fraternidade desse homem. Ele a deseja, ele a quer devorar, ele está tomado de fogo pelas carnes que ela é, foi seu amante, seu noivo, seu homem, mas jamais foi seu irmão: "quem dera fosses como um irmão para mim”, diz a heroína em 8,1. Se ele tivesse agido como um fraterno, se ele tivesse respeitado o desejo da heroína, ela não estaria em cativeiro. Antes, na expressão de seu convite àquele a quem seu desejo a impele, ela estaria no jardim, de volta ao jardim de delícias, sentindo o perfume das mandrágoras...

Se Édipo Rei e José são tragédias, e, de um jeito ou de outro, representam objetivamente o roteiro oracular, situando-se, ambos, retoricamente, ao lado do mitoplasma - os homens não podem de modo algum se furtar às determinações

39 Cf. a interpretação do refrão (Ct 2,7; 3,5; 8,4) como a advertência da heroína quanto aos efeitos negativos do desejo (GAULT, 2010). 
divinas -, Cântico dos Cânticos, incomparavelmente, a meu juízo, o livro mais espetacular da Bíblia Hebraica, diz que não há nada de divino nem oracular na condição trágica das pessoas, e que, se o roteiro trágico funciona na vida real, isso se deve única e exclusivamente ao conluio de pessoas, que até mesmo amamos e desejamos, com os donos do poder. No nível narrativo, a incompetência dos personagens nas duas primeiras tragédias finda por ilustrar a cumplicidade de pessoas reais que, na vida real, operam deliberadamente a favor das classes dominantes, pelo fato egoísta de, à custa de pessoas também reais, obterem benefícios no jogo das classes dominante e dominadas.

\section{Conclusão}

A proposição básica deste artigo é a seguinte: Édipo Rei é uma tragédia que se atualiza na forma de um enredo-tipo: a inutilidade dos esforços humanos para se furtarem aos desígnios divinos. Nessa específica tragédia, esse enredo-tipo se desenvolve na forma da tríplice tentativa de fuga a um destino perverso. Primeiro Laio e Jocasta, depois o escravo destes e, finamente, o próprio desgraçado Édipo, agindo na crença de escaparem do destino trágico estabelecido pelo oráculo, acabam promovendo-o.

A despeito de terrivelmente malfadado o destino de Édipo e superlativamente agraciado o destino de José, a história de José no Egito contém exatamente os mesmos elementos que Édipo Rei. Na forma de dois sonhos seus, o oráculo decreta que a família de José se curvará diante dele, o que é interpretado pelos irmãos como a presunção de governo. Correlativamente à estratégia de Laio e Jocasta, do escravo e do próprio Édipo, os irmãos de José decidem não se submeterem ao vaticínio, e, nesse caso, livram-se do irmão. No final das contas, os percalços por que passa José levam-no exatamente ao ponto anunciado pelo oráculo divino. A despeito do final positivo, e não negativo, José poderia ser classificada como uma narrativa trágica do tipo Édipo Rei.

Nesse sentido, ao menos em um primeiro momento, indispensável a um segundo, Cântico dos Cânticos deve ser classificado como um desdobramento do 
tipo de tragédia em que se classificam Édipo Rei e José. O oráculo determina que a mulher é intrinsecamente maldita e que, por força disso, seu castigo e destino é ser dominada por seu homem, para o qual seu próprio desejo a impelirá. Exatamente como Édipo e os irmãos de José, a heroína de Cântico dos Cânticos tenta fugir ao papel que lhe cabe no destino divinamente traçado, até certa altura julga ter logrado sucesso na estratégia e, de súbito, por meio de uma reviravolta extraordinária nos eventos, termina encontrando-se exatamente na situação da qual pretendeu fugir. Nesse sentido, até esse ponto da narrativa, Cântico dos Cânticos funciona exatamente como Édipo Rei e José. Até aqui, Cântico dos Cânticos se comporta como uma tragédia do tipo Édipo Rei.

Todavia, Cântico dos Cânticos vai além. O objetivo retórico de Cântico dos Cânticos é dissolver o enredo trágico, denunciando que o que se trata como oráculo divino não passa de um jogo de cumplicidade, conluio e compadrio entre a classe dominante, que opera o oráculo, e a parcela masculina da classe dominada, que se submete ao jogo da classe dominante e, por isso, promove a garantia do cumprimento daquilo que, no nível do oráculo, constitui maldição divina. Nesse sentido, o que em Édipo Rei e José aparece como incompetência tática dos personagens, o que é inexorável para o funcionamento da tragédia e sem o que não é possível sequer completar o fluxo narrativo, em Cântico dos Cânticos aparece como a cumplicidade da parcela masculina da classe dominada, sem cuja conivência e compadrio, a classe dominante não lograria encenar seu mitoplasma político-teológico.

\section{REFERÊNCIAS}

BAKON, S. Song of Songs. The Jewish Biblical Quarterly, Jerusalem, v. 22, n. 4, p. 11220, 1994.

BARBIERO, G. Song of Songs. A close reading. Leiden: Brill, 2011.

BARSTOW, M. Oedipus Rex as the Ideal Tragic Hero of Aristotle. The Classical Weekly, New York, v. 6, n. 1, p. 2-4, 1912.

BLACK, F. C. The artifice of love. Grotesque Bodies in the Song of Songs. New York: T. \& T. Clark, 2009. 
BLOCH, A; BLOCH, C. The Song of Songs: a new translation with an introduction and commentary. New York: Random House, 1995.

BLOOM, H. (ed.). Bloom's Modern Critical Interpretations. Oedipus Rex. Updated Edition. New York: Chelsea House, 2007.

BRUEGGEMANN, W. Genesis. Atlanta: John Knox Press, 1982.

CAVALCANTI, G. H. O Cântico dos Cânticos: um ensaio de interpretação através de suas traduções. São Paulo: EDUSP, 2005.

CHIEL, H. J. Joseph, the master of dreams. Tradition, New York, v. 39, n. 1, p. 5-20, 2005 .

DODDS, E. R. On Misunderstanding the 'Oedipus Rex'. Greece \& Rome, Cambridge, v. 13, n. 1, p. 37-49, 1966.

ECO, U. Interpretação e superinterpretação. São Paulo: Martins Fontes, 1993.

GAULT, B. P. An Admonition against "rousing love": the meaning of the enigmatic refrain in Song of Songs. Bulletin for Biblical Research, Overland Park, v. 20, n. 2, p. 161184, 2010.

GÊNESIS. Em: A Bíblia de Jerusalém. São Paulo, Paulinas, 1989.

GIRARD, R. A violência e o sagrado. 3. ed. São Paulo: Paz e Terra, 2008.

GOITEIN, S. D. Cântico dos Cânticos. Uma compilação feminina. In: BRENNER, A. Cântico dos Cânticos a partir de uma leitura de gênero. São Paulo: Paulinas, 2000. p. 65-74.

GROOTES, E.; SCHENKEVELD-VAN DER DUSSEN, R. Vondel's dramas: a choronological survey. In: BLOEMENDAL, F.; KORSTEN, F.-W. (ed.). Joost van den Vondel (1587-1679). Dutch Playwright in the Golden Age. Leiden: Brill, 2012. p. 1-6.

GUNKEL, H. Genesis. Macon: Mercer University Press, 1997.

HAY, P. Saturday. Between Tragedy and Triumph. Morrisville: Lulu.com, 2012.

KANE, R. L. Prophecy and Perception in the Oedipus Rex. Transactions of the American Philological Association, Baltimore, v. 105, p. 189-208, 1975.

KEEL, O. The Song of Songs. Minneapolis: Fortress Press, 1994.

KINGSMILL, E. The Song of Songs and the eros of God. Um study in biblical intertextuality. Oxford: Oxford University Press, 2009.

KOTHGASSER, A.; SEDMARK, C. Geben und Vergeben: Von der Kunst neu zu beginnen. Innsbruck: Tyrolia, 2008. 
LEVINSON, J. An-Other Woman: Joseph and Potiphar's Wife. Staging the Body Politic. The Jewish Quarterly Review, Pennsylvania, v. 87, n. 3, p. 269-301, 1997.

LONGACRE, R. E. Joseph: A story of divine providence. A text theoretical and textlinguistic analysis of Genesis 37 and 39-48. 2. ed. Winona Lake: Einsenbrauns, 2003.

MCGAHA, M. D. (ed.). The Story of Joseph in Spanish Golden Age Drama.

Lewisburg: Bucknell University Press, 1998.

MILLGRAM, H. L. The Joseph paradox: A radical reading of Genesis 37-50. Jefferson: McFarland, 2012.

MUNRO, J. M. Spikenard and Saffron. The imagery of the Song of Songs. Sheffield: Sheffield Academic Press, 1995.

PARENTE JR., J. A. Religious Drama and the Humanist Tradition. Christian Theater in Germany and in the Netherlands 1500-1680. Leiden: Brill, 1987.

QUASH, B. Four biblical characters. In search of tragedy. In: TAYLOR, K; WALLER, G. (ed.). Christian theology and tragedy. Theologians, tragic literature and tragic theory. New York: Routledge, 2011. p. 15-34.

RIBEIRO, O. L. Cântico dos Cânticos (7,10[11]) contra Gênesis (3,16) - um caso de intertextualidade programática subversiva. Estudos Teológicos, São Leopoldo, v. 53, n. 2, p. 312-324, 2014.

SCODEL, R. Hybris in the second atasimon of the Oedipus Rex. Classical Philology. Chicago, v. 77, n. 3, p. 214-223, 1982.

SIERHUIS, F. Therapeutic tragedy: compassion, remorse, and reconciliation in the Joseph plays of Joost van den Vondel (1635-1640). European Review of History: revue européenne d'histoire, London, v. 17, n. 1, p. 27-51, 2010.

SÓFOCLES. A trilogia tebana. Édipo rei. Édipo em Colono. Antígona. Tradução de Mario da Gama Kury. Rio de Janeiro: Jorge Zahar, 1998.

VERNANT, J.-P. Ambiguity and Reversal. On the Enigmatic Structure of Oedipus Rex. New Literary History, Baltimore, v. 9, n. 3, p. 475-501, 1978.

VERNANT, J.-P; VIDAL-NAQUET, P. Myth and Tragedy in Ancient Greece. New York: Zone Books, 1990.

VORSATZ, I. Antígona e a ética trágica da psicanálise. Rio de Janeiro: Zahar, 2013. ZENGER, E. Introdução ao Antigo Testamento. São Paulo: Paulus, 1998. 